
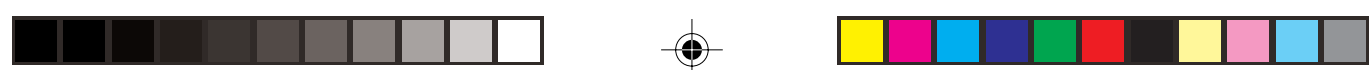

\title{
Photoessay
}

\section{Ben Bohane's portrayal of spirit and war in Melanesia}

Australia would do well to see itself as a large Pacific island rather than a continent removed from Asia and the Pacific.

\section{-Ben Bohane}

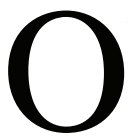

ver the past ten years, only a handful of enduring news items from the islands of Melanesia have made it into Australian and New Zealand mainstream media: Papua New Guinea's naval blockade after the Bougainville Revolutionary Army's (BRA) declaration of independence (and war) in 1989; Australia's troop deployment in East Timor as part of the UN's International Force in East Timor (INTERFET) in 1999; George Speight's attempt to overthrow the Fijian government in the coup and kidnapping of 2000; East Timor's achievement of full independence from Indonesia in 2002; the withdrawal from PNG of 210 Australian police officers following the collapse of the Enhanced Cooperation Pro-

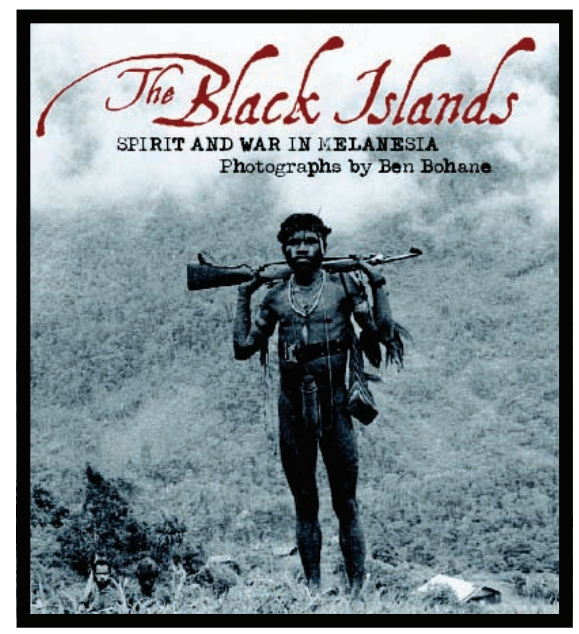

gramme (ECP) in 2005; the arrival of 43 West Papuan refugees on Cape York in January 2006 and the ethnically-targeted violence in Honiara, Solomon Islands, in April 2006.

The media maxim 'If it bleeds, it leads' may account for our tendency to focus on eruptions in a perceived status quo rather than monitoring the sequence of events that precede or influence them.

As a photojournalist, writer and producer of television documentaries, 


\section{ECO-JOURNALISM AND SECURITY}

Ben Bohane has spent the past 12 years posting stories about life on the islands of Melanesia to the Western media-illuminating the struggles and the spirit worlds behind the news. Melanesia is as close to Australia as a $150 \mathrm{~km}$ cruise from the tip of Cape York across the Torres Strait to Papua New Guinea, connecting Australasia to the rest of Oceania and Asia. Until recently, though, these islands have seemed distantly removed from Australia and New Zealand's notion of its international community.

As an Australian, resident in Vanuatu, I see myself as a Pacific islander and reject the grandiose claims of Australia being a 'continent'. I believe that this notion has blinded Australians to the reality that we remain forever linked to other Pacific islands through the blood and songlines of our indigenous people and our historical and military legacy in the region.

Bohane's long-standing journalistic focus in the region has been to explore the connections between kastom and resistance movements. Kastom is a broad term derived from the Tok Pisin (Melanesian pidgin) for 'custom', used to describe dynamic new religious movements with a traditional and spiritual base.

In certain cases, groups and cults absorb the characteristics of organised religion, particularly Christianity. For his first major assignment in the region in 1994, Bohane crossed the PNG naval blockade into Bougainville where he lived for two months with the BRA, documenting their activities and photographing their enigmatic leader Francis Ona. While researching and interviewing its members, Bohane discovered a connection between this revolutionary movement and kastom.

When the BRA first began their operations against the Panguna mine in 1989, they found refuge from the PNG Defence Force with the 50 Toea Movement, based in the Kongara mountains ...

It occurred to me then that kastom and cult movements were playing a significant-and completely unreported-role in the Bougainville conflict, and that numerous cults had been active against the German, Australian and Japanese administrations at various times over the past century. I had been hesitant at first, not wanting to make too much out of it or sensationalise this aspect, with lurid stories of 'crazy' cargo cults muddying the waters of what was already a complex political war. Over time, however, as I began covering other conflicts throughout Melanesia, such as in the Solomon Islands and West Papua, a similar pattern 


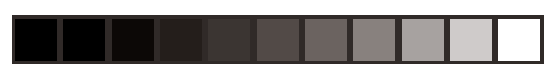

emerged. I came to realise that the role of these kastom and cult movements was not to be underestimated in any political analysis.

From Bougainville, Bohane travelled to West Papua (the Indonesian province of Irian Jaya) where the Papuan people's struggle for independence has been and still is, largely unreported due to Indonesia's restriction on news media access within the country. This so-called 'forgotten war' (Firth, 2005, p. 190) has cost tens of thousands of lives. Bohane's commitment to documenting the complexity of this conflict and the belief systems driving the Free Papua Movement (OPM) guerrillas, has not been made without serious repercussions.

In the case of Indonesia, I am still banned from entering the country because of my coverage of the struggles in West Papua and Maluku. I have been labelled a 'GPK' (security disturbance person) and was deported from Jakarta in 2002, the last time I tried to enter Indonesia.

As a photographer and writer, Bohane engages in a research methodology known as participatory action research (PAR) that aspires to engage all parties, observers and 'subjects' alike in a power-sharing dynamic

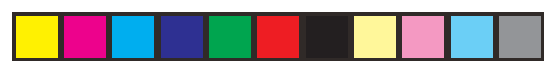

ECO-JOURNALISM AND SECURITY through informed consent-a far cry from the stereotype of photojournalist as shoot-and-run ambulance chaser, or cool and disconnected observer. Bohane's attentive practice would seem to complement the mercurial nature of political and religious change in the region. There are moments of stillness throughout the exhibition The Black Islands where the artist takes formal and direct portraits of the people he meets, landscape photographs, pictures of totems and architectural details that speak of a cultural immersion and sensitive interaction rather than the pursuit of a singular photographic instant.

The Black Islands is an exhibition that begins with photographs of the waters that connect Melanesia to its international trade and smuggling routes, moving in to explore the rugged landscapes, urban cities and jungle dwellings of the islands. Bohane's images of traditional practices, rituals and Christian-influenced cults convey a sense of peace and occasional levity that are contrasted with photographs of armed troops, conflict, protest, urban disintegration and the aftermath of war. In a selection of images that refer to the BRA's destruction of the Australian-operated Panguna mine site and the ensuing civil war, Bohane includes a photograph of a sick Australian mechanic 
ECO-JOURNALISM AND SECURITY

with his local wife, living through the blockade. This portrait injects a moment of quiet, living pathos into the story of exploitation, environmental catastrophe, fighting and payback.

From Bougainville and the BRA, Bohane has embarked upon a lifetime project to understand and interpret the influence of kastom in the region, including Australia. His photographs of kastom rituals and their influential leaders refer to more than the superficial or 'newsworthy' aspects of Melanesian culture. Bohane seeks to shed light on the powerful influence of the spirit world and belief systems that bind groups of people together, giving impetus to social changes and shifts in political hegemony.

\section{Bec Dean}

Curator

Australian Centre for Photography

\section{Reference}

Firth, S. (2005). Australian international politics. Sydney: Allen \& Unwin.

The Black Islands: Spirit and War in Melanesia, Australian Centre for Photography, Sydney, 8 September-14 October 2006. A selection of Bohane's photos appear on the next few pages. 